\title{
CALiPER Exploratory Study Office and Classroom Recessed Troffer Lighting - ARRA Report
}

NJ Miller

September 2012

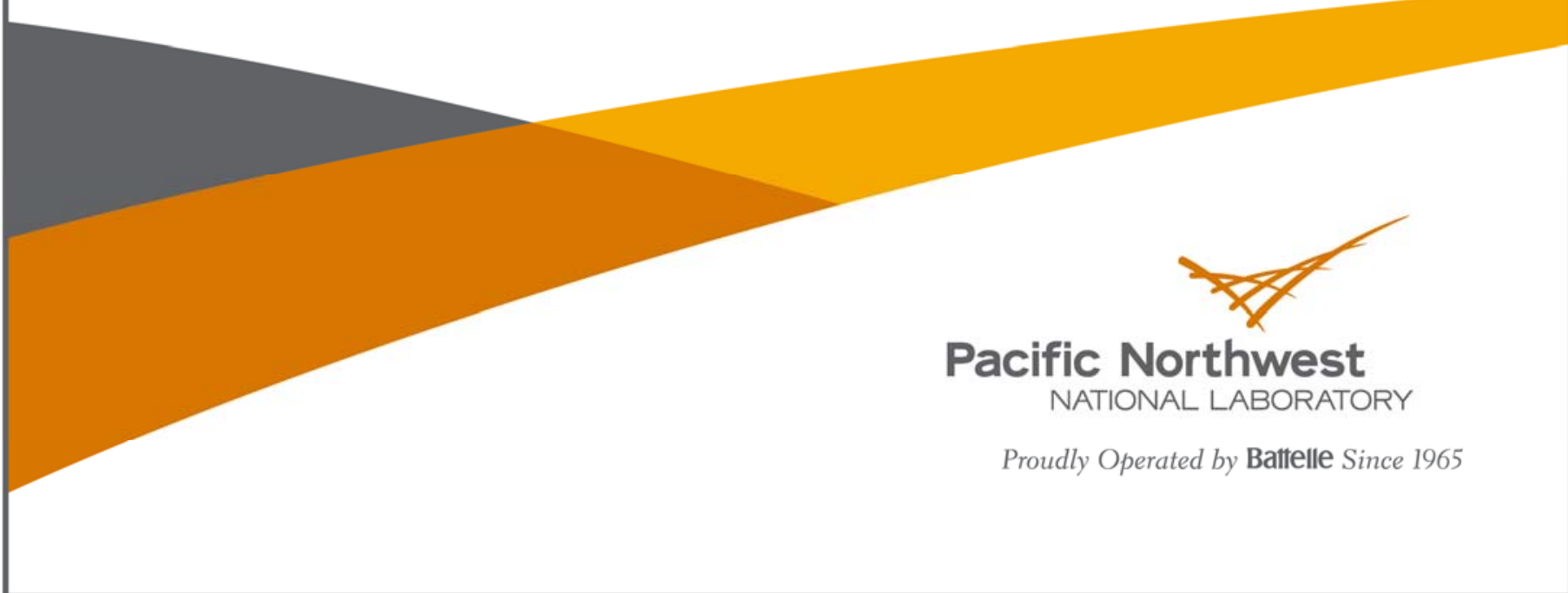




\title{
DISCLAIMER
}

This report was prepared as an account of work sponsored by an agency of the United States Government. Neither the United States Government nor any agency thereof, nor Battelle Memorial Institute, nor any of their employees, makes any warranty, express or implied, or assumes any legal liability or responsibility for the accuracy, completeness, or usefulness of any information, apparatus, product, or process disclosed, or represents that its use would not infringe privately owned rights. Reference herein to any specific commercial product, process, or service by trade name, trademark, manufacturer, or otherwise does not necessarily constitute or imply its endorsement, recommendation, or favoring by the United States Government or any agency thereof, or Battelle Memorial Institute. The views and opinions of authors expressed herein do not necessarily state or reflect those of the United States Government or any agency thereof.

\author{
PACIFIC NORTHWEST NATIONAL LABORATORY \\ operated by \\ BATTELLE \\ for the \\ UNITED STATES DEPARTMENT OF ENERGY \\ under Contract DE-AC05-76RL01830
}

\author{
Printed in the United States of America \\ Available to DOE and DOE contractors from the \\ Office of Scientific and Technical Information, \\ P.O. Box 62, Oak Ridge, TN 37831-0062; \\ ph: (865) 576-8401 \\ fax: $(865) 576-5728$ \\ email: reports@adonis.osti.gov

\begin{abstract}
Available to the public from the National Technical Information Service, U.S. Department of Commerce, 5285 Port Royal Rd., Springfield, VA 22161 ph: (800) 553-6847 fax: $(703) 605-6900$

email: orders@ntis.fedworld.gov

online ordering: http://www.ntis.gov/ordering.htm
\end{abstract}

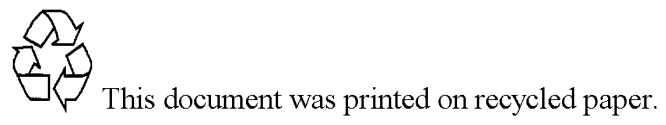

(9/2003) 


\section{CALiPER Exploratory Study Office and Classroom Recessed Troffer Lighting - ARRA Report}

NJ Miller

September 2012

Prepared for

the U.S. Department of Energy

under Contract DE-AC05-76RL01830

Pacific Northwest National Laboratory

Richland, Washington 99352 



\section{Contents}

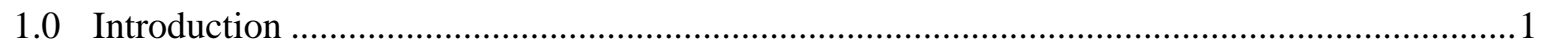

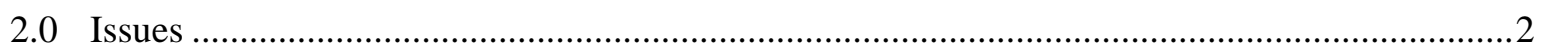

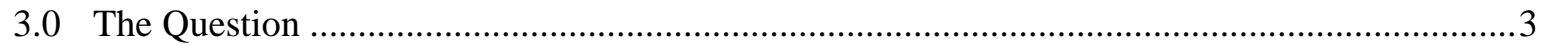

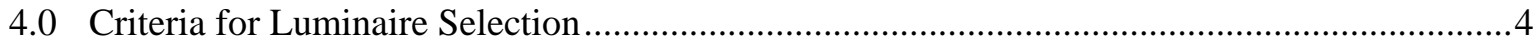

5.0 The Timeline and Process..................................................................................................

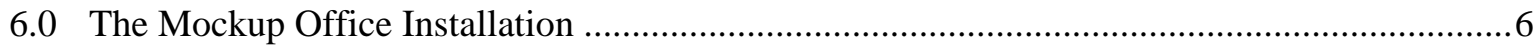

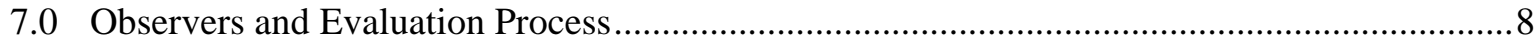

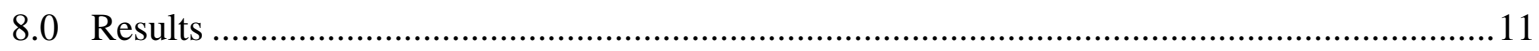

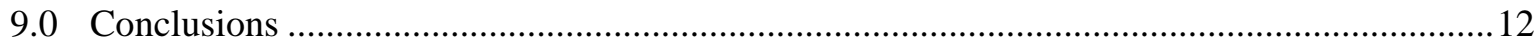




\section{Figures}

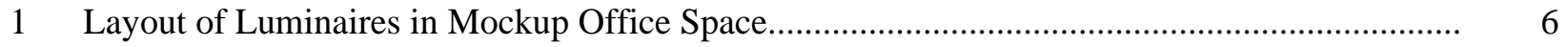

2 Evaluation Event Observers in Mockup Space for Initial Orientation ....................................... 8

3 Photo of Mockup Space Showing all Luminaires Switched On ............................................... 8

4 Ceiling of Mockup Space Showing 2x2 Luminaires Spaced on 8' x 8' Centers .......................... 9

5 Observers Evaluating Luminaires, using "Movable Wall" Positioned to Show

Light Pattern from Luminaire ................................................................................................. 9

6 Seated Observer is Looking for Severity of Reflection of Luminaire in Specular

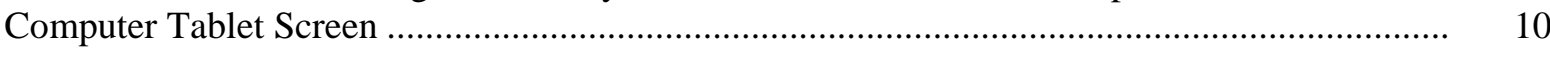

\section{Tables}

1 List of CALiPER Test Number, Mockup Label, Size, and Color-coded Product Types............... 


\subsection{Introduction}

This report is a brief summary of a project exploring LED versions of a very common luminaire type, the recessed troffer. It describes the planning and preparation for a mockup of 24 pairs of troffers in a simulated office space, where observations and comments were recorded. The questionnaire prompted detailed discussion of issues of LED troffers versus fluorescent troffers. The subsequent discussion informed the full group of observers on problems and benefits the specifier, facility manager, customer, and user will encounter as these products become more common in offices and classrooms. It also will inform future CALiPER studies and helped identify criteria for future evaluations 


\subsection{Issues}

Classrooms and offices have been principally lighted with fixtures using linear fluorescent lamps for decades: Recessed 2x4s, 2x2s, 1x4s; Linear direct/indirect or indirect pendants; Chalkboard/whiteboard lights and linear wallwashers. The T8 and T5 fluorescent lamps and electronic ballasts are a robust, mature technology. If not well-liked, at least they have been tolerated. Maintenance is fairly easy and although there's a wide range of lamp, ballast, and luminaire types, there is some consistency in installation methods, controls, and expected performance over time.

Enter the LEDs. The design team, facility manager, electrician, contractor, and user are all facing big changes in the "Type A recessed fixture" on the lighting plan, and in existing buildings where the lighting needs a facelift for energy or appearance reasons.

- Some manufacturers are offering T8 LED replacement lamps, either with a replacement of ballast with a driver, or with tubes with integral drivers.

- Some manufacturers are offering 2x4 and 2x2 luminaires with dedicated LEDs and drivers. Some use a small number of high-output LEDs, and others use a larger number of low-output LEDs.

- Some manufacturers are offering a "kit" to upgrade a fluorescent troffer to an LED option. In most cases the fluorescent troffer's housing is retained, the ballast is replaced with a driver which powers linear boards of LEDs. The kit either uses the luminaire's existing lens or optical system, or replaces it with a diffusing acrylic panel for a refreshed look.

Some LED products mimic the fluorescent products’ optical performance, but most simply deliver a cosine (or "blob") distribution. This may or may not work in terms of luminaire spacing for ceiling or workplane uniformity, for visual comfort, or for reducing reflected glare on computer screens. 


\subsection{The Question}

How well do these LED products perform compared to conventional fluorescent troffers in terms of

- Photometric distribution (direct glare, reflected glare, overhead glare, uniformity of light on task surface, spacing criteria, suitability for task)

- Power Quality (THD, PF)

- Flicker, especially when dimmed in response to daylight or occupancy sensing

- Dimming performance (smoothness of dimming, minimum dimmed output)

- Color quality

- Light output (too much or too little given the spacing?)

- Ease of installation, including LED retrofit kits and T8 LED tubes

- Maintainability (cleaning) and replaceability of LED boards and drivers

- Energy efficiency (lumens-per-watt of installed luminaire and lighting power density of typical installation)

- Economic viability and life cycle cost 


\subsection{Criteria for Luminaire Selection}

In selecting luminaires for this study, the following criteria were used so that as much as possible, luminaires served similar functions and were comparable:

- Recessed 2x2 or 2x4 troffer luminaire, designed for mounting in a 9' acoustical T-bar ceiling

- Target of 4000K, CRI >80 (Although 3500K is the more common CCT for fluorescent luminaires in the USA, more LED luminaires were available in $4000 \mathrm{~K}$, so the criteria was shifted accordingly)

- 2500 to 6000 luminaire lumens

- 0-10V dimmable ballasts or drivers if available

- Target Spacing Criteria (SC) min. of 1.2 in both directions

- For dedicated LED troffers, LM-79 report for specific product available

- Power factor $>0.9$

- Range of optics, appearances, prices, and expected qualities 


\subsection{The Timeline and Process}

The following describes the timeline for developing and planning the study and the mockup event:

- Products, including fluorescent benchmarks, researched from March to May 2012

- Products ordered May 18-29, 2012. Receiving deadline for inclusion in the project was July 31, 2012

- Products and their arrival condition were documented once received by PNNL. They were wired and equipped with a cord and plug for $120 \mathrm{~V}$ power and dimming control wires. They were taken to the PNNL flicker testing lab for measurement, sphere tested for color and flux at PNNL, then either shipped to a CALiPER-approved testing lab for LM-79 testing, or shipped directly to the host site. The PNNL laboratory testing was performed in June and July 2012.

- Products that were "kits" or "LED tube retrofits" were installed in two types of conventional T8 fluorescent toffers, also procured for this study. An architectural construction electrician was hired by PNNL in Richland to perform the retrofit given the manufacturer-supplied instructions. The install time and his comments on the ease of this work were documented. Completed retrofitted troffers were shipped to independent photometric labs in July-August 2012 for goniophotometry testing. Tested fixtures were shipped to Intertek facility for installation in late August 2012.

- Intertek Testing Laboratory in Fairview OR was contracted to install a temporary office mockup at their facility, with 24 pairs of troffers controlled by an Encellium control system. Intertek's subcontractors did an excellent job of building the mockup office space and installing the luminaires. Intertek also has accommodated visits for follow-up measurements.

- An Intertek engineer, expert in field certification of luminaires visited the mockup site in the week before the evaluation event. He inspected the retrofitted products and provided feedback on the NRTL listing and certification status of the luminaires.

- PNNL contracted with 17 IALD designers/engineers to attend the mockup event and help evaluate the luminaires. Most of these observers were from independent lighting and engineering firms located across the USA. One uncompensated observer was an energy manager from a Portland-based healthcare organization.

- The evaluation event with IALD members, electrical engineers, a facility manager and energy efficiency expert was organized and held from September 5-7, 2012. The eyes-on event asked independent lighting experts to complete questionnaires and provide feedback and group discussion on the issues identified. 


\subsection{The Mockup Office Installation}

Twenty-four pairs of 2x2 or 2x4 luminaires were installed in a 9' acoustical ceiling at the mockup facility. The layout was designed to space luminaires uniformly within the room, on typical spacings. 2x4 troffers were spaced on 10' centers parallel to the length of the room, and 2x2 luminaires on 8' centers perpendicular to the room. In order for the room to look and function like a real office, four pairs of luminaires were switched together: 2x4s on 8' x 10' spacing, 2x2s on 8' x 8' spacing. See Figure 1.

There were two movable sheetrock walls created, so that observers could position the "wall" at a typical distance from the luminaire so that its pattern of light on vertical surfaces could be evaluated. Ceiling tile reflectance was approximately $80 \%$, wall reflectance $70 \%$ (white), and floor reflectance was concrete (approximately 30\%). Two movable desks were located in the space, with laptop computers and paper tasks for evaluating visibility and reflections. (Participants in the study provided several iPads, with highly specular screens, for evaluating reflected glare from the luminaires.)

The luminaires were equipped with interfaces for the Encellium dimming system, and wired with 0$10 \mathrm{~V}$ control wire. This allowed each pair of luminaires to be individually controllable apart from all other luminaires. The control system was programmed to switch and dim groups of luminaires as needed for the evaluation process and for group viewing.

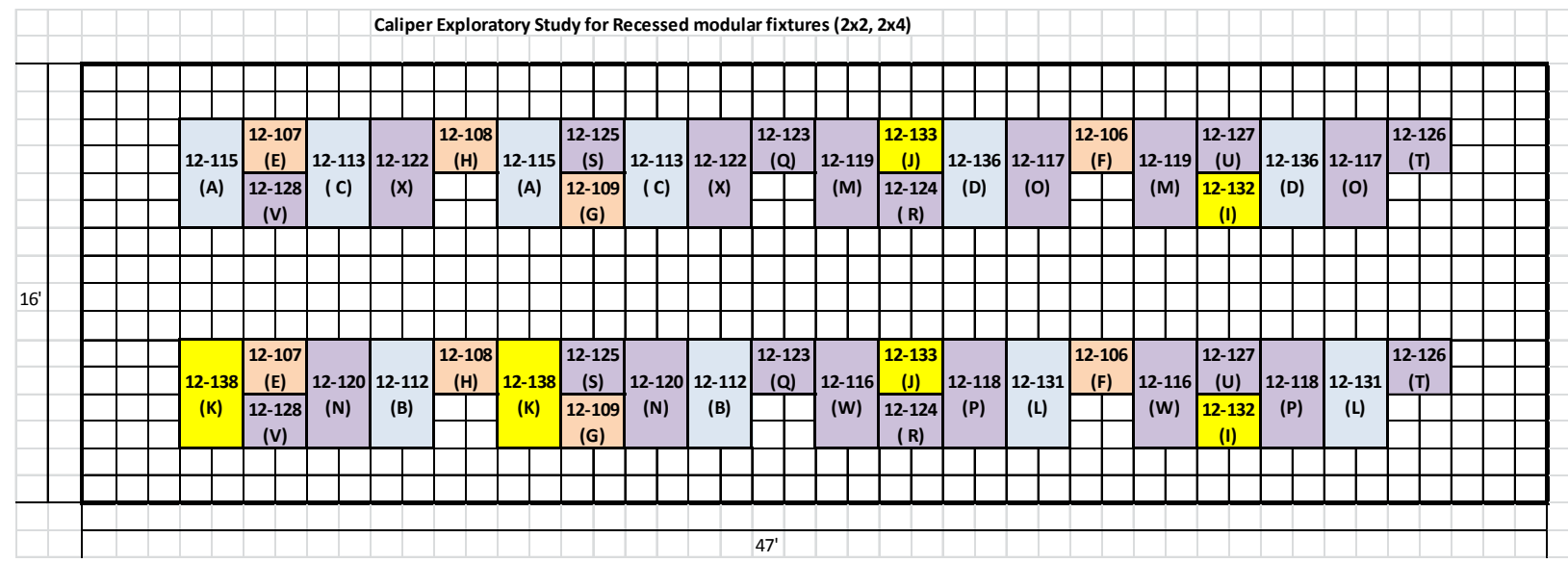

Figure 1. Layout of Luminaires in Mockup Office Space. Each luminaire is labeled with its mockup label (A-X) and its CALiPER test number (e.g. 12-125).

A brief description of the products follows. Each is color-coded as shown in Table 1. 
Table 1. List of CALiPER Test Number, Mockup Label, Size, and Color-coded Product Types

\begin{tabular}{|c|c|c|c|}
\hline Caliper \# & Tag & Size & Type \\
\hline $12-115$ & A & $2 \mathrm{x} 4$ & T8 LED tubes \\
\hline $12-112$ & B & $2 \times 4$ & T8 LED tubes \\
\hline $12-113$ & $\mathrm{C}$ & $2 \times 4$ & T8 LED tubes \\
\hline $12-136$ & $\mathrm{D}$ & $2 \times 4$ & T8 LED tubes \\
\hline $12-107$ & $\mathrm{E}$ & $2 \times 2$ & LED Retrofit kit \\
\hline $12-106$ & $\mathrm{~F}$ & $2 \times 2$ & LED Retrofit kit \\
\hline $12-109$ & G & $2 \times 2$ & LED Retrofit kit \\
\hline $12-108$ & $\mathrm{H}$ & $2 \times 2$ & LED Retrofit kit \\
\hline BK-12-132 & I & $2 \times 2$ & Fluor BK \\
\hline BK-12-133 & $\mathrm{J}$ & $2 \times 2$ & Fluor BK \\
\hline BK-12-138 & $\mathrm{K}$ & $2 \times 4$ & Fluor BK \\
\hline $12-131$ & $\mathrm{~L}$ & $2 \times 4$ & T8 LED tubes \\
\hline $12-119$ & M & $2 \times 4$ & New LED troff \\
\hline $12-120$ & $\mathrm{~N}$ & $2 \times 4$ & New LED troff \\
\hline $12-117$ & $\mathrm{O}$ & $2 \times 4$ & New LED troff \\
\hline $12-118$ & $\mathrm{P}$ & $2 \times 4$ & New LED troff \\
\hline $12-123$ & $\mathrm{Q}$ & $2 \times 2$ & New LED troff \\
\hline $12-124$ & $\mathrm{R}$ & $2 \times 2$ & New LED troff \\
\hline $12-125$ & $\mathrm{~S}$ & $2 \times 2$ & New LED troff \\
\hline $12-126$ & $\mathrm{~T}$ & $2 \times 2$ & New LED troff \\
\hline $12-127$ & U & $2 \times 2$ & New LED troff \\
\hline $12-128$ & $\mathrm{~V}$ & $2 \times 2$ & New LED troff \\
\hline $12-116$ & W & $2 \times 4$ & New LED troff \\
\hline $12-122$ & $\mathrm{X}$ & $2 \times 4$ & New LED troff \\
\hline
\end{tabular}




\subsection{Observers and Evaluation Process}

Eighteen observers participated in the evaluation event. They were divided into groups of 6, and were presented with four pairs of luminaires illuminated at full output. The order of presentation to groups of participants was counterbalanced to mitigate order effects. Observers were asked to complete a questionnaire without communication among the group. After being presented with all six groups of luminaires, the observers then saw the same groups of luminaires, in different order, in dimming mode. They responded to a questionnaire on their observations of the dimming performance, again without discussion among the group. (See Figures 2-6.) At the end of the evaluation session, all observers were brought together to discuss what they had seen, what they had learned, and what qualities were important to convey to the specifier and user in this and future CALiPER studies.

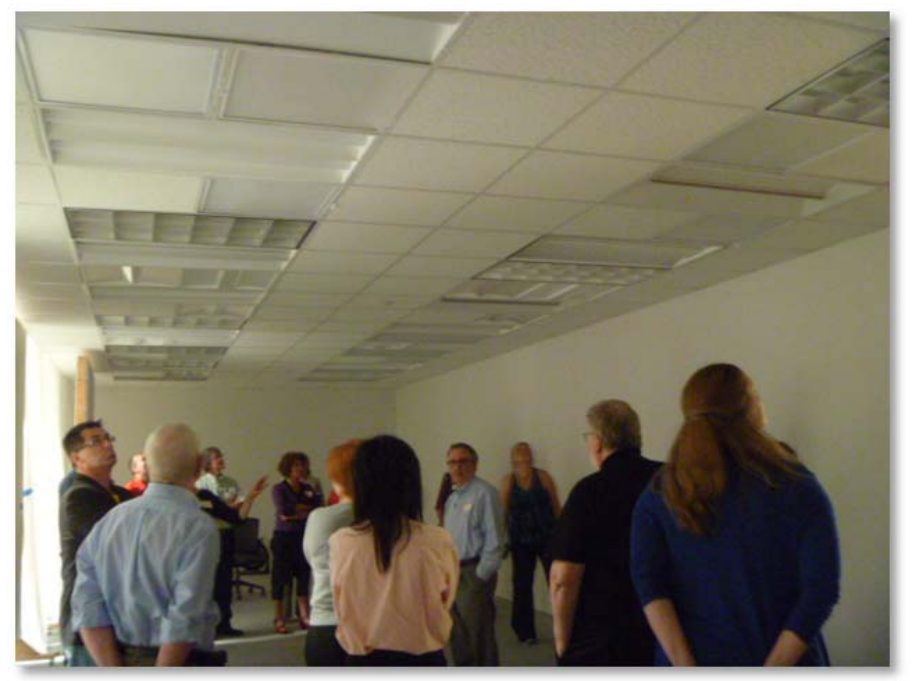

Figure 2. Evaluation Event Observers in Mockup Space for Initial Orientation

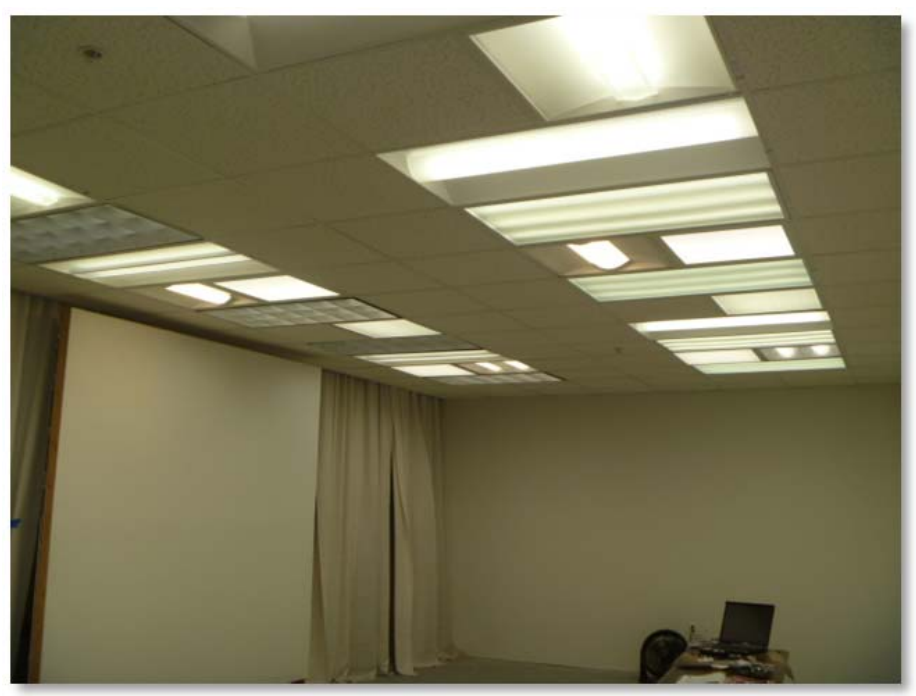

Figure 3. Photo of Mockup Space Showing all Luminaires Switched On 


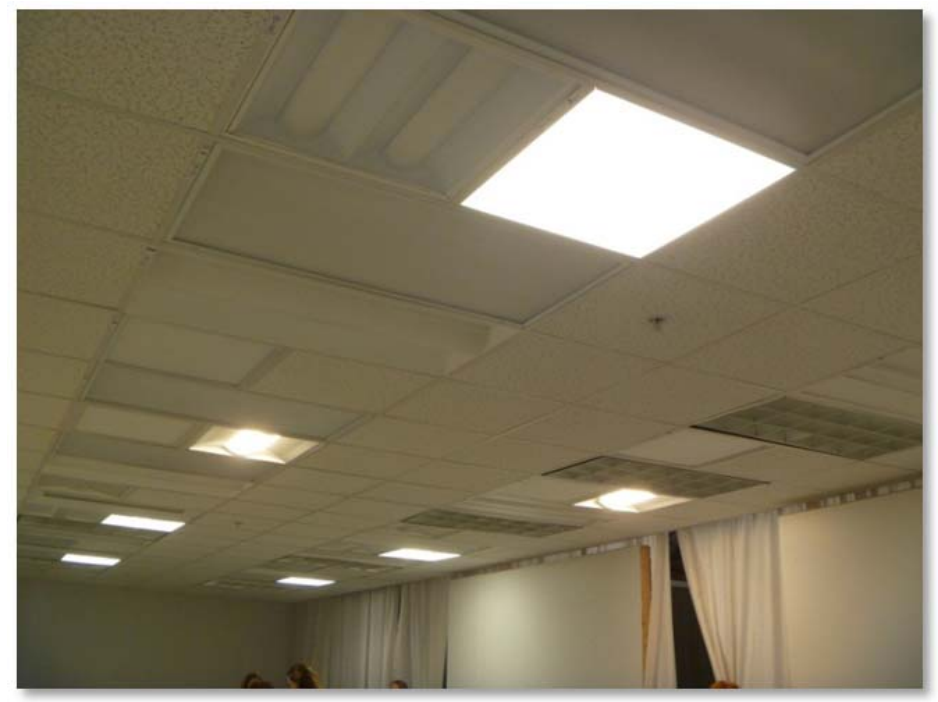

Figure 4. Ceiling of Mockup Space Showing 2x2 Luminaires Spaced on 8' x 8' Centers

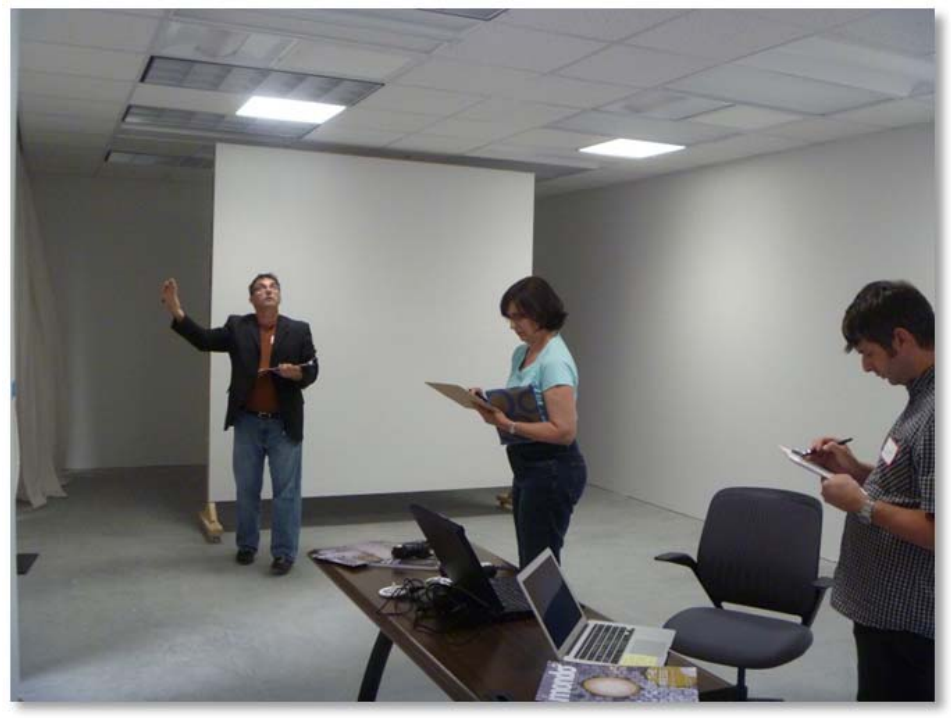

Figure 5. Observers Evaluating Luminaires, using "Movable Wall" Positioned to Show Light Pattern from Luminaire 


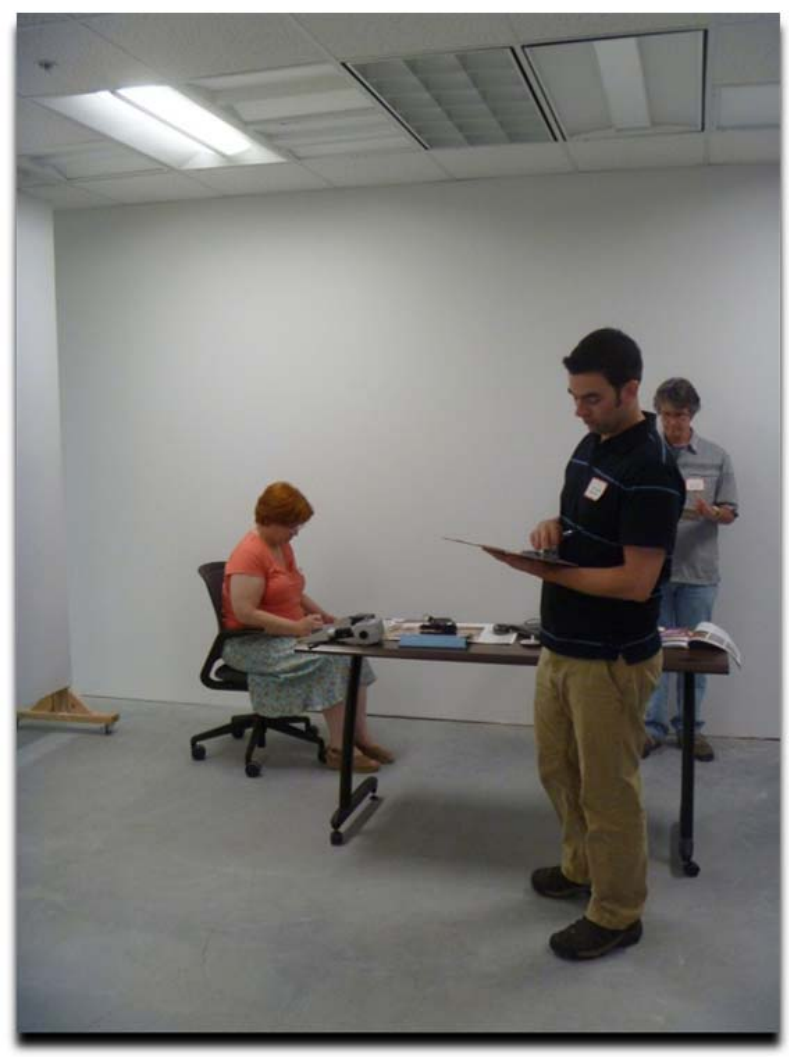

Figure 6. Seated Observer is Looking for Severity of Reflection of Luminaire in Specular Computer Tablet Screen 


\subsection{Results}

Eighteen well-respected, influential designers and engineers and facility engineers have now experienced a wide range of recessed troffers, and have become empowered to communicate about the opportunities that LEDs offer. They will in turn teach colleagues and clients about screen reflections, dimming performance, flicker, the inconsistencies of CCT color selection, and more.

The questionnaire results and the subsequent discussion identified several areas of concern over LED troffers:

- Color inconsistency among products that were all ordered to be “4000K” white

- The presence of annoying flicker under dimmed conditions for some (but not all) products, and how there is no way to identify in advance whether a product will exhibit flicker or not

- The increased contrast introduced by T8 LED replacement lamps in parabolic troffers (bright lamp as viewed against an upper reflector that receives no light from the back side of the LED tube) and increased "striping" in prismatic lens troffers where there is little reflected light from the housing reflector to add bounced light to the lens surface, thereby reducing the luminance of the lamp image against the luminance of the lens area between lamps.

- Increased concern over the contrast of flat diffuser luminaires (and other diffuser-based luminaires) against the surrounding acoustical ceiling. A sharp edge in contrast is created, which images in shiny computer screens.

- Dimming performance in some products was far from the smooth and predictable performance seen in fluorescent troffers with dimming ballasts.

- There is widespread concern about the performance and safety issues surrounding T8 LED replacement lamps and kits. Intertek’s post-conversion inspection of the fluorescent luminaires modified with retrofit kits provided invaluable information for the study's participants on the conditions for preserving NRTL certification and listing of the products.

The level of importance placed on difference performance parameters will help develop criteria for evaluating LED luminaires for CALiPER in the future. Input from the observer/specifiers and facility managers will be communicated to manufacturers to improve LED lighting product offerings. 


\subsection{Conclusions}

This CALiPER study trained eighteen designers/engineers in identifying and specifying successful LED troffers for office and classroom use. Participants are now familiar with flicker profiles, detecting flicker in in-situ luminaires, how to identify direct and reflected glare issues and which metrics may predict problems, NRTL luminaire safety listings and the effect of modifications on those listings, the wide variety of colors that fall in the category of $4000 \mathrm{~K}$ "white”, and the varieties of dimming curves in response to $0-10 \mathrm{~V}$ controller settings. As a result, these specifiers and facility managers and their colleagues and clients will have a better idea of how to evaluate LED products, and what tradeoffs are acceptable versus those which are non-negotiable on their specific applications.

This CALiPER study will inform future product evaluations so that additional lighting quality issues, such as flicker, are documented and communicated. Solid-state troffer products are entering the market at a rapid rate, and the CALiPER program is tasked with investigating and reporting on product quality to support adoption (where appropriate), dramatic energy reductions, and long-term satisfaction. CALiPER strives to improve the decision-making process for energy-efficient architectural lighting. 



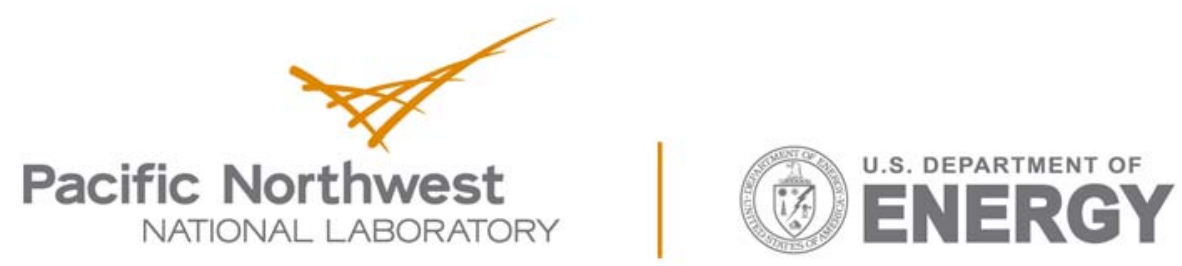

Proudly Operated by Battelle Since 1965

902 Battelle Boulevard

P.O. Box 999

Richland, WA 99352

1-888-375-PNNL (7665)

www.pnnl.gov 